\title{
List of illustrations and tables
}

\section{Plates}

Plates 1-16 begin opposite page 72

1 Gyr Falcon skins from Henry Dresser's collection (courtesy of Manchester Museum, The University of Manchester)

2 Female and male Steller's Eider by J. G. Keulemans, from Sharpe, R. B. and H. E. Dresser (1871), A History of the Birds of Europe (part 3, rebound as vol. 7, plate 447) (C) The University of Manchester)

3 Male Smew, Norfolk (C) David Tipling)

4 Buff-breasted Sandpiper by J. G. Keulemans, from Dresser, H. E. (1876), A History of the Birds of Europe (part 47-8, rebound as vol. 8, plate 561) (C) The University of Manchester)

5 Map showing Henry Dresser's routes through Texas, based on Johnson's New Map of the State of Texas (1866) from the New Illustrated Family Atlas of the World with Physical Geography, and with Descriptions Geographical, Statistical, and Historic, Including the Latest Federal Census, a Geographical Index, and a Chronological History of the Civil War in America (public domain / Wikimedia Commons)

6 Curlew Sandpiper by J. G. Keulemans, from Dresser, H. E. (1878), A History of the Birds of Europe (part 67-8, rebound as vol. 8, plate 553) (C) The University of Manchester)

7 Glossy Ibis by J. G. Keulemans, from Dresser, H. E. (1878), A History of the Birds of Europe (part 71-2, rebound as vol. 6, plate 409) (C) The University of Manchester)

8 Philip Sclater, from Henry Dresser's album of correspondents (English Manuscript 1404, John Rylands Library, (C) The University of Manchester)

9 Richard Bowdler Sharpe, from Henry Dresser's album of correspondents (English Manuscript 1404, John Rylands Library, (C) The University of Manchester)

10 Edmund Harting, from Henry Dresser's album of correspondents (English Manuscript 1404, John Rylands Library, (C) The University of Manchester)

11 Henry Elwes, from Henry Dresser's album of correspondents (English Manuscript 1404, John Rylands Library, (C) The University of Manchester) 
12 Waxwing adults, nest and chicks by J. Gould and H. C. Richter based on specimens collected by Henry Dresser, from Gould, J. (1867), The Birds of Great Britain (C) The University of Manchester)

13 Golden-cheeked Warbler by J. G. Keulemans, from Salvin, O. (1876), 'On Dendroica chrysoparia' (C) The University of Manchester)

14 Hooded Merganser male (foreground), female (swimming) and chicks by J. G. Keulemans, from Dresser, H. E. (1896), Supplement to A History of the Birds of Europe (part 6, rebound as plate 696) (C) The University of Manchester)

15 Male and female Surf Scoter by J. G. Keulemans, from Dresser, H. E. (1877), A History of the Birds of Europe (part 61-2, rebound as vol. 6, plate 450) (C) The University of Manchester)

16 Flock of Knot flying in to roost, Norfolk (C) David Tipling)

Plates 17-32 begin opposite page 136

17 Northern Bald Ibis by J. G. Keulemans, from Dresser, H. E. (1880), A History of the Birds of Europe (part 77-9, rebound as vol. 6, plate 408) (C) The University of Manchester)

18 Male and female Caucasian Grouse by J. G. Keulemans, from Dresser, H. E. (1875), A History of the Birds of Europe (part 41-2, rebound as vol. 7, plate 488) (C) The University of Manchester)

19 'Labrador Falcon' (dark-phase Gyr Falcon) by J. G. Keulemans, based on a bird in Henry Dresser's collection (shown in plate 1, see also plate 47). From Dresser, H. E. (1876), 'Falco labradorus (Labrador Falcon)'

(C) The University of Manchester)

20 Snowy Owl by J. G. Keulemans, from Dresser, H. E. (1873), A History of the Birds of Europe (part 22, rebound as vol. 5, plate 309) (C) The University of Manchester)

21 Illustration of the heads of Yellow Wagtails, drawn by Edwin Brooks and sent to Henry Dresser (courtesy of Manchester Museum, The University of Manchester)

22 Crossbills by J. G. Keulemans, from Dresser, H. E. (1872), A History of the Birds of Europe (part 14, rebound as vol. 4, plate 203) (C) The University of Manchester)

23 Map of southern Central Asia, showing localities mentioned in the text. Background image derived from NASA, Visible Earth, Blue Marble: land surface, shallow water, and shaded topography. Background image courtesy of NASA Goddard Space Flight Center. Image by Reto Stöckli (land surface, shallow water, clouds). Enhancements by Robert Simmon (ocean color, compositing, 3D globes, animation). Data and technical support: MODIS Land Group; MODIS Science Data Support Team; MODIS Atmosphere Group; MODIS Ocean Group Additional data: USGS EROS Data Center (topography); USGS Terrestrial Remote Sensing Flagstaff Field Center (Antarctica); Defense Meteorological Satellite Program (city lights) 
24 Arctic Terns, Shetland (C) David Tipling)

25 Coal Tits by J. G. Keulemans, including the British subspecies Periparus ater britannicus named by Sharpe and Dresser, from Sharpe, R. B. and H. E. Dresser (1872), A History of the Birds of Europe (part 11-12, rebound as vol. 3, plate 107) (C) The University of Manchester)

26 Black Woodpecker at nest hole, Finland (C David Tipling)

27 Heinrich Gätke, from Henry Dresser's album of correspondents (English Manuscript 1404, John Rylands Library, (C) The University of Manchester)

28 Saker Falcon by J. Wolf, from Dresser, H. E. (1879), A History of the Birds of Europe (part 73-74, rebound as vol. 6, plate 376)

(C) The University of Manchester)

29 Chicks of Little Stint, Temminck's Stint and Dunlin by J. G. Keulemans, from Dresser, H. E. (1876), A History of the Birds of Europe (part 47-8, rebound as vol. 8, plate 550) (C) The University of Manchester)

30 Hume's Warbler as Yellow-browed Warbler by J. G. Keulemans, from Dresser, H. E. (1874), A History of the Birds of Europe (part 29-30, rebound as vol. 2, plate 74) (C) The University of Manchester).

31 Immature Spotted Eagle, India (C David Tipling)

32 Road in Upper Norwood by Camille Pissarro (1871). This appears to show Henry Dresser's house (St Margaret's) (C) bpk | Bayerische Staatsgemäldesammlungen, courtesy of the Neue Pinakothek, Munich)

Plates 33-47 begin opposite page 168

33 Hairy-fronted Muntjac by J. Smit, from Sclater, P. L. (1885), 'Report on the additions to the Society's menagerie in December 1884, and description of a new species of Cervulus' (C) The University of Manchester)

34 Arabian Green Bee-eater by J. G. Keulemans, from Dresser, H. E. (1884), A Monograph of the Meropidae (part 2) (C) The University of Manchester)

35 Red-bearded Bee-eater by J. G. Keulemans, from Dresser, H. E. (1884), A Monograph of the Meropidae (part 1) (C) The University of Manchester)

36 Short-legged Ground Roller by J. G. Keulemans, from Dresser, H. E. (1893), A Monograph of the Coraciidae (C) The University of Manchester)

37 'Eastern Shore-lark' by J. G. Keulemans, from Dresser, H. E. (1874), A History of the Birds of Europe (part 32, rebound as vol. 4, plate 244) (C) The University of Manchester)

38 Greenshank by J. G. Keulemans, from Sharpe, R. B. and H. E. Dresser (1871), A History of the Birds of Europe (part 5, rebound as vol. 8, plate 570) (C) The University of Manchester)

39 Black-eared Wheatear Oenanthe hispanica as Saxicola stapazina by J. G. Keulemans, from Dresser, H. E. (1874), A History of the Birds of Europe (part 25, rebound as vol. 2, plate 23) (C) The University of Manchester) 
40 Syrian Serin Serinus syriacus as Tristram's Serin Serinus canonicus by J. G. Keulemans, from Dresser, H. E. (1876), A History of the Birds of Europe (part 49, rebound as vol. 3, plate 171) (C) The University of Manchester)

41 British Marsh Tit Poecile palustris dresseri, Norfolk (C) David Tipling)

42 Coracias weigalli by J. G. Keulemans, from Dresser, H. E. (1893), A Monograph of the Coraciidae (C) The University of Manchester)

43 Coracias mosambicus by J. G. Keulemans, from Dresser, H. E. (1893), A Monograph of the Coraciidae (C) The University of Manchester)

44 The extinct Canary Islands Oystercatcher (as African Black Oystercatcher) by J. G. Keulemans, from Dresser, H. E. (1896), Supplement to A History of the Birds of Europe (part 7, rebound as plate 711) (image from the Biodiversity Heritage Library, digitised by the Smithsonian Institution Libraries, www.biodiversitylibrary.org)

45 Desertas Petrel (as Soft-plumaged Petrel) by J. G. Keulemans, from Dresser, H. E. (1896), Supplement to A History of the Birds of Europe (part 9, rebound as plate 721) (C) The University of Manchester)

46 Pallas's Warbler, Burnham Overy Dunes, Norfolk, October 2010 (C) David Tipling)

47 'Labrador Falcon' (dark-phase Gyr Falcon) painted by J. Wolf in 1875, based on a specimen in Henry Dresser's collection (shown in plate 1, see also plate 19) (private collection, courtesy of the owner)

Plates 48-62 begin opposite page 264

48 Lanius funereus by J. G. Keulemans, from Dresser, H. E. (1895), Supplement to A History of the Birds of Europe (part 4, rebound as plate 667) (C) The University of Manchester)

49 Seebohm's Wheatear Oenanthe oenanthe seebohmi as Saxicola seebohmi by J. G. Keulemans, from Dresser, H. E. (1895), Supplement to A History of the Birds of Europe (part 1, rebound as plate 636) (C) The University of Manchester)

50 Photographic plate of the eggs of rare thrushes from Dresser, H. E. (1901), 'On some rare or unfigured Palaearctic birds eggs' (C) The University of Manchester)

51 Permafrost tundra, Kolyma, Siberia, 1994 (C) Staffan Widstrand)

52 Ross's Gull on nest in marsh, Chukochyi river-mouth tundra, Kolyma, June 1994 (C) Staffan Widstrand)

53 Photographic plate of Ross's Gull eggs collected by Sergei Buturlin in 1905, from Dresser, H. E. (1906), 'Note on the eggs of Ross's Rosy Gull' (C) The University of Manchester)

54 Plate of the chicks of Ross's Gull and Pectoral Sandpiper by J. G. Keulemans, from Buturlin, S. A. (1907), 'On the breeding-habits of the Rosy Gull and the Pectoral Sandpiper' (C) The University of Manchester)

55 Spectacled Eider male and female, National Petroleum Reserve, near Point Barrow, Alaska (C) Steven Kazlowski) 
56 Asian Dowitcher by J. G. Keulemans, from Dresser, H. E. (1909), 'On the occurrence of Pseudoscolopax taczanowskii in Western Siberia' (C) The University of Manchester)

57 Pechora Pipit Anthus gustavi as Anthus seebohmi by J. G. Keulemans, from Dresser, H. E. (1875), A History of the Birds of Europe (part 45, rebound as vol. 3, plate 174) (C) The University of Manchester)

58 Peregrine Falcon by J. G. Keulemans, from Dresser, H. E. (1875), A History of the Birds of Europe (part 46, rebound as vol. 6, plate 372) (C) The University of Manchester)

59 Red-bearded and Blue-bearded Bee-eaters from Henry Dresser's collection (courtesy of Manchester Museum, The University of Manchester)

60 Steller's Eider specimens from Henry Dresser's collection. The bird in the foreground is from Varanger Fjord, Norway, and formed the basis of the illustration shown in plate 2 (courtesy of Manchester Museum, The University of Manchester)

61 Slender-billed Curlew, Merja Zerga, Morocco, 1995 (C) Chris Gomersall)

62 Steller's Eider males, with male Common Eider and King Eider, Båtsfjord, Varanger Peninsula, Norway, 2016 (C) Paul Hobson)

\section{Figures}

I.1 Papers and photographs that belonged to Henry Dresser

I.2 John Henry Gurney junior, from Henry Dresser's album of correspondents (English Manuscript 1404, John Rylands Library,

(C) The University of Manchester)

I.3 Cartoon of John Lubbock, the 'banking busy bee', from Punch, 19 August 1882, p. 82 (C) The University of Manchester)

I.4 Lucy Audubon (wife of John James Audubon), from Henry Dresser's album of correspondents (English Manuscript 1404, John Rylands Library, (C) The University of Manchester)

I.5 Horatio Wheelwright (the 'Old Bushman'), from Henry Dresser's album of correspondents (English Manuscript 1404, John Rylands Library, (C) The University of Manchester)

1.1 Topcliffe, the waterfall and mill, c.1955 (C) The Francis Frith Collection)

1.2 Photograph of Henry Dresser aged around twenty (courtesy of the Central Archives for Finnish Business Records (ELKA), Mikkeli, Finland, Hackman Oy, photograph no. 452)

1.3 Mounted Waxwing chicks and nest, collected by Henry Dresser in Finland in 1858 (courtesy of Manchester Museum, The University of Manchester)

1.4 'Map of Musquash River and Lancaster Mills, 1868', from Dresser, A. R., Travels in New Brunswick, Canada and Manitoba (p. 6) (C) The Trustees of the British Museum) 
1.5 'Plan of Lancaster Mills and Inglewood Manor 1869', from Dresser, A. R., Travels in New Brunswick, Canada and Manitoba (p. 8) (C) The Trustees of the British Museum)

1.6 'Lancaster Mills from the Manor House winter 1870', from Dresser, A. R., Travels in New Brunswick, Canada and Manitoba (p. 7) (C) The Trustees of the British Museum)

1.7 Edward Booth, from Henry Dresser's album of correspondents (English Manuscript 1404, John Rylands Library,

(C) The University of Manchester)

1.8 Alfred Newton, from Henry Dresser's album of correspondents (English Manuscript 1404, John Rylands Library,

(C) The University of Manchester)

1.9 George Boardman, from Henry Dresser's album of correspondents (English Manuscript 1404, John Rylands Library,

(C) The University of Manchester)

1.10 'My camp and hovel at Deer Brook, Lancaster Mills, Musquash N.B. while logging during the winter of 1870 \& 1871', from Dresser, A. R., Travels in New Brunswick, Canada and Manitoba (p. 7) (C) The Trustees of the British Museum)

1.11 Roualeyn Gordon-Cumming, from Henry Dresser's album of correspondents (English Manuscript 1404, John Rylands Library, (C) The University of Manchester)

2.1 Henry Dresser's diary of his time in Texas, and his copybook of letters (courtesy of Manchester Museum, The University of Manchester)

2.2 Buff-breasted Sandpiper collected by Henry Dresser in Matamoros (courtesy of Manchester Museum, The University of Manchester)

2.3 Powder magazine at Fort Duncan, Eagle Pass, Texas. Now part of the Fort Duncan Museum (courtesy of Patrick Ogren)

3.1 The Firs, South Norwood Hill, from Dresser, A. R., Travels in New Brunswick, Canada and Manitoba (p. 1) (C) The Trustees of the British Museum)

3.2 Whitehall (formerly The Firs), South Norwood Hill, 1960, by F. Merton Atkins (image courtesy of the Museum of Croydon)

3.3 Statue of Arthur Forwood, in front of St George's Hall, Liverpool (author's photograph)

3.4 Portrait of Henry Dresser aged twenty-six (courtesy of the Central Archives for Finnish Business Records (ELKA), Mikkeli, Finland, Hackman Oy, photograph no. 453)

3.5 Count Ercole Turati, from Henry Dresser's album of correspondents (English Manuscript 1404, John Rylands Library,

(C) The University of Manchester) 
3.6 Sir Antonio Brady, from Henry Dresser's album of correspondents (English Manuscript 1404, John Rylands Library, (C) The University of Manchester)

3.7 Trade advertisement for the Bowling Iron Company, from Post Office London Trades' Directory (1891) (courtesy of Grace's Guide to British Industrial History, www.gracesguide.co.uk, accessed 8 April 2017)

4.1 John Gould, from Henry Dresser's album of correspondents (English Manuscript 1404, John Rylands Library,

(C) The University of Manchester)

4.2 Joseph Wolf and photographs of Wolf's tombstone, from Henry Dresser's album of correspondents (English Manuscript 1404, John Rylands Library, (C) The University of Manchester)

4.3 Lord Lilford, from Henry Dresser's album of correspondents (English Manuscript 1404, John Rylands Library,

(C) The University of Manchester)

4.4 Arthur Hay as Viscount Walden, from Henry Dresser's album of correspondents (English Manuscript 1404, John Rylands Library, (C) The University of Manchester)

4.5 Frederick Godman, from Henry Dresser's album of correspondents (English Manuscript 1404, John Rylands Library, (C) The University of Manchester)

5.1 Rare hybrid grouse from Henry Dresser's collection. The bird in the foreground is a Black Grouse x Red Grouse hybrid purchased among gamebirds in Leadenhall Market (courtesy of Manchester Museum, The University of Manchester)

5.2 John Wolley, from Henry Dresser's album of correspondents (English Manuscript 1404, John Rylands Library,

(C) The University of Manchester)

5.3 Henry Dresser's auction catalogues, marked with prices paid at auction for specimens (courtesy of Manchester Museum, The University of Manchester)

5.4 Heinrich Möschler, from Henry Dresser's album of correspondents (English Manuscript 1404, John Rylands Library, (C) The University of Manchester)

5.5 James Hepburn, from Henry Dresser's album of correspondents (English Manuscript 1404, John Rylands Library,

(C) The University of Manchester)

5.6 Swallow-tailed Kite study skin and eggs from Henry Dresser's collection (courtesy of Manchester Museum, The University of Manchester)

5.7 Spencer Baird, from Henry Dresser's album of correspondents (English Manuscript 1404, John Rylands Library,

(C) The University of Manchester) 
5.8 Robert Collett, from Henry Dresser's album of correspondents (English Manuscript 1404, John Rylands Library,

(C) The University of Manchester)

6.1 John Harvie-Brown, from Henry Dresser's album of correspondents (English Manuscript 1404, John Rylands Library,

(C) The University of Manchester)

6.2 Alfred Benzon, from Henry Dresser's album of correspondents (English Manuscript 1404, John Rylands Library,

(C) The University of Manchester)

6.3 Kammerråd H. C. Erichsen, from Henry Dresser's album of correspondents (English Manuscript 1404, John Rylands Library, (C) The University of Manchester)

6.4 Wilhelm Meves, from Henry Dresser's album of correspondents (English Manuscript 1404, John Rylands Library,

(C) The University of Manchester)

6.5 Howard Saunders, from Henry Dresser's album of correspondents (English Manuscript 1404, John Rylands Library, (C) The University of Manchester)

6.6 Ross's Gull specimens from Henry Dresser's collection, collected on the First International Polar Year Expedition to Point Barrow (courtesy of Manchester Museum, The University of Manchester)

7.1 Robert Swinhoe, from Henry Dresser's album of correspondents (English Manuscript 1404, John Rylands Library,

(C) The University of Manchester)

7.2 Jules Verreaux, from Henry Dresser's album of correspondents (English Manuscript 1404, John Rylands Library,

(C) The University of Manchester)

7.3 Nikolai Severtzov, from Henry Dresser's album of correspondents (English Manuscript 1404, John Rylands Library,

(C) The University of Manchester)

7.4 William Blanford, from Henry Dresser's album of correspondents (English Manuscript 1404, John Rylands Library,

(C) The University of Manchester)

7.5 Henry Tristram, from Henry Dresser's album of correspondents (English Manuscript 1404, John Rylands Library,

(C) The University of Manchester)

7.6 Ernest Shelley, from Henry Dresser's album of correspondents (English Manuscript 1404, John Rylands Library,

(C) The University of Manchester)

8.1 Title page from Dresser, H. E. (1882), A History of the Birds of Europe (part 83-4, rebound in vol. 1), showing Henry Dresser's monogram including a wise owl by J. Wolf (C) The University of Manchester) 
8.2 'A lecture on embryology' by J. Wolf; the text on the lectern translates as 'Highly learned makes a fool' (from Palmer, 1895, opposite p. 180, public domain / Wikimedia commons)

9.1 Photograph of the grave of Thomas Jerdon, provided to subscribers who paid for the tombstone, from Henry Dresser's album of correspondents (English Manuscript 1404, John Rylands Library, (C) The University of Manchester)

9.2 Thomas Buckley, from Henry Dresser's album of correspondents (English Manuscript 1404, John Rylands Library,

(C) The University of Manchester)

9.3 Letter and photographic portrait from Charles Darwin, from Henry Dresser's album of correspondents (English Manuscript 1404, John Rylands Library, (C) The University of Manchester)

9.4 Henry Feilden, from Henry Dresser's album of correspondents (English Manuscript 1404, John Rylands Library,

(C) The University of Manchester)

9.5 Henry Seebohm, from Henry Dresser's album of correspondents (English Manuscript 1404, John Rylands Library,

(C) The University of Manchester)

10.1 'Meeting of the Zoological Society at Hanover Square' by H. Furniss, from Scherren, H. (1905), The Zoological Society of London (public domain / Wikimedia commons)

11.1 Walter Rothschild, from Henry Dresser's album of correspondents (English Manuscript 1404, John Rylands Library,

(C) The University of Manchester)

11.2 Ernst and Claudia Hartert, from Henry Dresser's album of correspondents (English Manuscript 1404, John Rylands Library,

(C) The University of Manchester)

11.3 William Hoyle, from Henry Dresser's album of correspondents (English Manuscript 1404, John Rylands Library,

(C) The University of Manchester)

12.1 Portrait of Henry Dresser, aged around sixty (courtesy of Manchester Museum, The University of Manchester)

12.2 Nikolai Zarudny, from Henry Dresser's album of correspondents (English Manuscript 1404, John Rylands Library,

(C) The University of Manchester)

12.3 Sergei Buturlin, from Henry Dresser's album of correspondents (English Manuscript 1404, John Rylands Library,

(C) The University of Manchester)

12.4 Photograph of a boy climbing to a Buzzard's nest, taken by Baron Harald Loudon in June 1904 (courtesy of Manchester Museum, The University of Manchester)

12.5 Photograph of Henry Dresser with a Redwing's nest, taken by Baron Harald Loudon in June 1904 (courtesy of Manchester Museum, The University of Manchester) 
13.1 Henry Dresser's album of photographs of nests (courtesy of Manchester Museum, The University of Manchester)

13.2 Photographic plate of twelve Knot eggs collected on the Russian Polar Expedition, from Dresser, H. E. (1909), Eggs of the Birds of Europe (plate 83) (C) The University of Manchester)

13.3 Bird skins Henry Dresser received from Laurence Waddell and named as new species: Babax waddelli, Garrulax tibetanus and Lanius lama (courtesy of Manchester Museum, The University of Manchester)

13.4 Photograph showing the inside of Sergei Buturlin's hut in Pokhodskoe, Kolyma, 1905, with dead birds and eight Ross's Gull skins on the windowsill. Note the trap hanging from the wall and stuffing hanging from the ceiling (courtesy of Manchester Museum, The University of Manchester, ZDH/2/1/4)

14.1 The BOU fiftieth anniversary dinner, held at the Trocadero Restaurant in Piccadilly Circus on 9 December 1908, from Henry Dresser's album of correspondents (English Manuscript 1404, John Rylands Library, (C) The University of Manchester)

14.2 William Tegetmeier 'aged 92 years can still write firmly owing to the absence of the poison known as alcohol', from Henry Dresser's album of correspondents (English Manuscript 1404, John Rylands Library, (C) The University of Manchester)

14.3 Baron Harald Loudon, from Henry Dresser's album of correspondents (English Manuscript 1404, John Rylands Library,

(C) The University of Manchester)

14.4 Lord Avebury as 'A modern St. Francis', by B. Partridge, Punch, 27 May 1908, issue 3520, p. 382. Reproduced in Bird Notes and News, 24 June 1908, vol. 3, issue 1, opposite p. 13 (image from the Biodiversity Heritage Library, digitised by the American Museum of Natural History Library, www.biodiversitylibrary.org)

14.5 Alfred Wallace, from Henry Dresser's album of correspondents (English Manuscript 1404, John Rylands Library,

(C) The University of Manchester)

14.6 Henry Dresser, aged around seventy (courtesy of the Library of Congress, Washington DC, Ruthven-Deane Collection)

15.1 The cover of The Oologists' Record (1921), showing an illustration of the rare Red Kite and its nest (image from the Biodiversity Heritage Library, digitised by the American Museum of Natural History Library, www.biodiversitylibrary.org) 
Appendix images

All images in appendix 1, 'Birds mentioned in the text', are from

Dresser, H. E. (initially Sharpe, R. B. and H. E. Dresser) (1871-82), A History of the Birds of Europe (from the Biodiversity Heritage Library, digitised by the Smithsonian Institution Libraries, www.biodiversitylibrary.org)

\section{Endpapers}

Heads of swans by J. G. Keulemans, from Dresser, H. E. (1880), A History of the Birds of Europe (part 77-9, rebound as vol. 6, plate 419) (C) The University of Manchester)

\section{Tables}

8.1 Subscribers to A History of the Birds of Europe 
Henry A. McGhie - 9781526116017 